\title{
List of Works
}

\section{Published under the Auspices of the School of Oriental and African Studies}

1946-1990 
[The works included in this list have been published either entirely at the expense of the School or with substantial assistance from the School's publications fund. All prices shown are subject to alteration without notice. Orders should be placed through normal trade channels.

The list does not include the many works by members of the academic staff of the School published without assistance from the publications fund.]

Published by School of Oriental and African Studies. (Orders should be sent to the Publications Officer, School of Oriental and African Studies, Thornhaugh Street, Russell Square, London WC1H OXG.)

*An asterisk indicates that the book has been transferred from the original publisher, and is now distributed by the School.

Collected Papers in Oriental and African Studies

$£ p$.

1. M. Guthrie (ed.): African Language Studies I (1960)

$10 \quad 00$

2. M. Guthrie (ed.): African Language Studies II (1961)

$10 \quad 00$

3. M. Guthrie (ed.): African Language Studies III (1962)

$10 \quad 00$

4. H. L. Shorto (ed.): Linguistic Comparison in South East Asia and the Pacific (1963)

5. M. Guthrie (ed.): African Language Studies IV (1963)

$8 \quad 00$

5. M. Guthrie (ed.). African Language Studies IV (1963)

$10 \quad 00$

6. M. Guthrie (ed.): African Language Studies V (1964)

$10 \quad 00$

7. M. Guthrie (ed.): African Language Studies VI (1965)

$10 \quad 00$

8. M. Guthrie (ed.): African Language Studies VII (1966) .

$10 \quad 00$

I. Richardson and W. M. Mann: A vocabulary of Su̧kú̧ma (African Language Studies VII Offprint) (1967)

A. V. King: A. Bòoríi Liturgy from Katsina (African Language Studies VII Supplement) (1967)

9. M. Guthrie (ed.): African Language Studies VIII (1967)

10. M. Guthrie (ed.): African Language Studies IX (1968)

11. M. Guthrie (ed.): African Language Studies X (1969)

12. W. G. Atkins (ed.).: African Language Studies XI (1970)

13. W. H. Whiteley (ed.): African Language Studies XII (1971)

14. W. H. Whiteley (ed.): African Language Studies XIII (1972)

15. D. W. Arnott (ed.): African Language Studies XIV (1973)

16. D. W. Arnott (ed.): African Language Studies XV (1974)

17. D. W. Arnott (ed.): African Language Studies XVI (1975)

18. G. Innes (ed.): African Language Studies XVII (1980)

\section{INAUGURAL LECTURES}

A. N. Allott: Law and Language (1965)

o.p.

J. N. D. Anderson: The Relevance of Oriental and African Legal Studies (1954)

A. L. Basham: The Indian Sub-Continent in Historical Perspective (1958)

C. E. Bazell: Linguistic Typology (1958)

W. G. Beasley: The Basis of Japanese Foreign Policy in the Nineteenth Century (1955) .

o.p.

o.p.

o.p.

C. F. Beckingham: The Achievements of Prester John (1966) 
F. J. Daniels: Japanese Studies in the University of London and Elsewhere (1963)

J. D. M. Derrett: An Oriental Lawyer looks at the Trial of Jesus and the Doctrine of the Redemption (1966) .

C. A. Fisher: The Reality of Place (1965)

C. J. Gadd: Teachers and Students in the Oldest Schools (1956)

A. Gledhill: Whither Indian Law? (1956)

S. H. Hansford: The Study of Chinese Antiquities (1956)

E. J. A. Henderson: The Domain of Phonetics (1965)

P. M. Holt: The Study of Modern Arab History (1965)

A. K. S. Lambton: Islamic Society in Persia (1954)

D. M. Lang: Landmarks in Georgian Literature (1966)

R. A. Oliver: African History for the Outside World (1964)

E. T. Penrose: Economics and the Aspirations of le tiers Monde (1965)

R. H. Robins: General Linguistics within a Liberal Education (1966)

N. C. Scott: The Place of Phonetics in the University (1961)

J. B. Segal: Edessa and Harran (1963)

R. B. Serjeant: The Saiyids of Hadramawt (1957)

Hugh Tinker: The City in the Asian Polity (1964)

D. C. Twitchett: Land Tenure and the Social Order in T'ang and Sung China (1962)

E. Ullendorff: The Challenge of Amharic (1965) .

W. Watson: Inner Asia and China in the Pre-Ham Period (1969)

D. J. Wiseman: The Expansion of Assyrian Studies (1962).

J. C. Wright: Non-Classical Sanskrit Literature (1966)

o.p.

$o . p$.

200

200

o.p.

200

200

o.p.

o.p.

o.p.

200

200

200

200

o.p.

200

o.p.

o.p.

o.p.

200

o.p.

\section{Foundation Day Lectures}

H. W. Butterfield: History and Man's Attitude to the Past (1961)

Sir Eric Ashby: Patterns of Universities in Non-European Societies (1961) .

Sir Hamilton Gibb: Area Studies Reconsidered (1963)

200

200

Sir Keith Hancock: Smuts and the Shift of World Power (1964).

Sir Willis Jackson: Technology and the Developing Countries (1966)

200

200

Philip Mason: Race Relations: A Field of Study comes of Age (1968)

O. Lattimore: Britain's Opportunity in Asian Studies (1970) .

A. T. Hatto: Shamanism and Epic Poetry in Northern Asia (1970)

Lord Fulton: The Expanding World of the Universities (1972) .

200

o.p.

o.p.

200

The Gandhi Memorial Lecture

Krishna Kripalani: Gandhi, the Modern Mahatma (1970) . 
WORKS PUBLISHED UNDER THE AUSPICES OF S.O.A.S.

Fascicle III (1955)

Fascicle IV (1963)

Fascicle V (1969)

Fascicle VI (1981)

The set of six

\section{OTHER WORKS}

B. W. Andrzejewski: The Declensions of Somali Nouns (1964)

E. Balazs: Political Theory and Administrative Reality in Traditional China (1965)

J. Brough: Selections from Classical Sanskrit Literature (Second edition 1978)

J. H. Carter: Syntax and Tone in Kongo (1973)

J. H. Carter and G. P. Kahari: Kuverenga ChiShóna (Second edition 1987), 2 parts .

T. W. Clark: Introduction to Nepali (Second edition 1977) .

J. H. C. S. Davidson (ed.): La⿳亠 Sū' Thai: essays in honour of Professor E. H. S. Simmonds (1987)

o.p.

o.p.

$\begin{array}{ll}4 & 00\end{array}$

600

$6 \quad 00$ o.p.

$6 \quad 00$

J. H. C. S. Davidson (ed.): Pacific Island Languages: essays in honour of G. B. Milner (1990)

J. H. C. S. Davidson (ed.): South-East Asian Linguistics: essays in honour of Eugénie J. S. Henderson (1989) .

1200

900

J. H. C. S. Davidson and H. Cordell (ed.): The Short Story in South East Asia: aspects of a genre (1982)

A. Gacek: Catalogue of the Arabic Manuscripts in the Library of the School of Oriental and African Studies, University of London (1981)

A. C. Graham: Later Mohist Logic, Ethics and Science [Published in Hong Kong by the Chinese University Press] (1978)

A. C. Graham: Chuang-tzǔ: textual notes to a partial translation (1982)

M. Guthrie: Bantu Sentence Structure (1961)

700

o.p.

$16 \quad 00$

o.p.

o.p.

$7 \quad 00$

R. A. Hamilton (ed.): History and Archaeology in Africa-First Conference (1955)

R. J. Hayward (ed.): Omotic Language Studies (1990)

R. Hedinger: The Manenguba Languages (Bantu A.15, Mbo cluster) of Cameroon (1987)

M. Hiskett: A. History of Hausa Islamic Verse (1975)

P. J. Honey (trans. and ed.): P. J. B. Truong-vĩnh-Ký: Voyage to Tonking in the Year Ât-họi (1876) (1982)

E. Hook: A Guide to the Papers of John Swire and Sons Ltd. (1977)

M. J. Hutt: Nepali-a National Language and its Literature (1988).

G. Innes: The Structure of Sentences in Mende (1963)

G. Innes: An Introduction to Grebo (1966)

G. Innes: A Practical Introduction to Mende (1967)

G. Innes: Sunjata-Three Mandinka Versions (1974)

G. Innes: Kaabu and Fuladu: Historical Narratives of the Gambian Mandinka (1976)

G. Innes: Kelefa Saane-His Career Recounted by Two Mandinka Bards (1978)

o.p.

$32 \quad 00$

$17 \quad 00$

$10 \quad 00$

$8 \quad 00$

$6 \quad 00$

1200

o.p.

$6 \quad 00$

800

$10 \quad 00$

1100

900 
T. M. Johnstone: Mehri Lexicon and English-Mehri Word-list (1987)

D. H. Jones (ed.): History and Archaeology in Africa-Second Conference (1959)

H. Kabir: Rabindranath Tagore (1962)

E. U. Kratz: Bibliography of Indonesian Literature in Journals (1989).

B. Lewis (ed.): The Fall of Constantinople (1955)

D. L. R. Lorimer: The Wakhi Language (1958).

G. H. Luce: A Comparative Word-List of Old Burmese, Chinese and Tibetan (1981)

\section{$£ p$. \\ $20 \quad 00$ \\ 300 \\ $\begin{array}{ll}4 & 00\end{array}$ \\ $30 \quad 00$ \\ o.p. \\ o.p.}

400

1200

$18 \quad 00$

500

300

600

500

700

1000

600

500

800 House Pvt. Ltd.] (1978)

P. G. O'Neill: A Programmed Introduction to Literary-Style Japanese (1968) .

J. W. A. Okell: First Steps in Burmese (with 5 cassettes) (1989) .

R. Pankhurst (ed.): Tax Records and Inventories of Emperor Téwodros of Ethiopia (1855-1868) (1978) .

E. M. Parker and R. J. Hayward: An Afar-English-French Dictionary (1985)

C. H. Philips and M. D. Wainwright (ed.): Indian Society and the Beginnings of Modernisation c. 1830-1850 (1976).

Johan Pottier (ed.): Food Systems in Central and Southern Africa (1986)

I. M. P. Raeside: Gadyarāja, a fourteenth century version of the Krșna legend (1989)

C. H. B. Reynolds: Sinhalese, an Introductory Course (1980)

I. Richardson: The Role of Tone in Sukúma (1959)

M. C. Ricklefs: Modern Javanese Historical Tradition: a study of an orginial Kartasura chronicle and related materials (1978)

E. C. Rowlands: A Grammar of Gambian Mandinka (1959)

N. C. Scott: A Dictionary of Sea Dayak (1956) .

C. Shackle: The Siraiki Language of Central Pakistan, a Reference Grammar (1976).

C. Shackle: A Gurū Nānak Glossary (1981) . . . .

C. Shackle: An Introduction to the Sacred Language of the Sikhs (1983)
600

$30 \quad 00$

$10 \quad 00$

$10 \quad 00$

o.p.

800

$20 \quad 00$

$20 \quad 00$

o.p.

$14 \quad 00$

$10 \quad 00$

o.p.

$10 \quad 00$

1200

800 
C. Shackle (ed.): Urdu and Muslim South Asia, studies in honour of Ralph Russell (1989) . . . . . . .

S. R. Schram (ed.): The Scope of State Power in China (1985)

S. R. Schram (ed.): Foundations and Limits of State Power in China (1987)

W. E. Skillend: Kodae Sosŏl (1969)

T. Skorupski (ed.): The Buddhist Forum, Volume I (1990).

N. V. Smith: Outline Grammar of Nupe (1967) .

R. B. Smith and A. J. Stockwell (ed.): British Policy and the Transfer of Power in Asia-Documentary Perspectives (1988)

P. A. Stott (ed.): Nature and Man in South East Asia (1978)

R. L. Turner: A Comparative Dictionary of the Indo-aryan Languages: Addenda and Corrigenda (1985)

E. Ullendorff: An Amharic Chrestomathy (Second edition 1978)

M. D. Wainwright (ed.): Brothers in India: the correspondence of Tom, Alfred and Christopher Bassano, 1841-75 (1979)

E. O. J. Westphal: Kwangari-an Index of Lexical Types (1959)

W. H. Whiteley: Some Problems of Transitivity in Swahili (1968)

M. H. Williams: Catalogue of the Papers of Sir Charles Addis (1986).

W. A. A. Wilson: An Outline of Temne (1962) . . . . .

I. Yamada: Karuñāpuṇdarika (1968)
S.O.A.S.-Library: Cumulated list of Periodical Articles on the Far East and South East Asia, May 1956-April 1957 (1958).

S.O.A.S.-Library: Cumulated List of Periodical Articles on the Far East and South East Asia, May 1957-April 1958 (1959)

SOAS South Asian TeXts

1. C. Shackle and R. Snell: Hindi and Urdu since 1800: a common reader (1990)

OcCasional Papers in Third-World Economic History

1. G. Balachandran: India in Britain's Liquidity Crisis: the stabilization of $1920(1990)$

\section{JoRDAN LECTURES IN COMPARATIVE RELIGION}

[For Volumes 1-12 see The Athlone Press]

13. D. Seyfort Ruegg: Buddha-nature, Mind and the Problem of Gradualism in a Comparative Perspective, on the transmission and reception of Buddhism in India and Tibet (1989)

14. Jonathan Z. Smith: Drudgery Divine, on the comparison of early Christianities and the religions of Late Antiquity (1990)

Published by the School of Oriental and African Studies for the Corpus INSCRIPTIONUM IRANICARUM

M. Shokoohy: Haryana I-The Column of Fìrūz Shāh and other Islamic Inscriptions from the District of Hisar (1988)

N. Sims-Williams: Sogdian and other Iranian Inscriptions of the Upper Indus I (1989)

N. Sims-Williams and J. Hamilton: Documents turco-sogdiens du IXe-Xe siècle de Touen-houang (1990) . 
W. Sundermann: The Manichaean Hymn Cycles Huyadagmān and Angad Rōšnān in Parthian and Sogdian (1990)

Published by OXFORD UNIVERSITY PRESS

London ORIENTAL SERIES

*1. W. S. Allen: Phonetics in Ancient India (1953)

900

2. J. B. Segal: The Diacritical Point and the Accents in Syriac (1953)

*3. Mary Boyce: The Manichaean Hymn Cycles in Parthian (1954)

o.p.

900

4. E. G. Pulleyblank: The Background of the Rebellion of An LuShan (1955)

5. K. Ballhatchet: Social Policy and Social Change in Western India, 1817-1830 (1957)

6. D. L. Snellgrove: The Hevajra Tantra (1959)

*7. J. Brough: The Gāndhārī Dharmapada (1962)

8. C. J. Dowsett: The History of the Caucasian Albanians by Movsēs Dasxuranci (1961).

*9. D. N. MacKenzie: Kurdish Dialect Studies I (1961)

*10. D. N. MacKenzie: Kurdish Dialect Studies II (1962)

11. C. D. Cowan: Nineteenth-Century Malaya-the Origins of British Political Control (1961)

12. J. B. Segal: The Hebrew Passover from the Earliest Times to A.D. 70 (1963)

*13. F. R. Palmer: The Morphology of the Tigre Noun (1962)

14. R. Williams: Jaina Yoga (1963) [Reprinted by Motilal Banarsidass, 1983]

*15. E. J. A. Henderson: Tiddim Chin: a Descriptive Analysis of Two Texts (1965)

16. V. L. Ménage: Neshri's History of the Ottomans: the Sources and Development of the Text (1965)

*17. T. M. Johnstone: Eastern Arabian Dialect Studies (1967)

18. D. L. Snellgrove: The Nine Ways of Bon (1967)

*19. R. E. Emmerick: Tibetan Texts concerning Khotan (1967)

*20. R. E. Emmerick: Saka Grammatical Studies (1968)

*21. R. E. Emmerick: The Book of Zambasta (1968) .

*22. D. N. MacKenzie: The "Sūtra of the Causes and Effects of Actions" in Sogdian (1970)

*23. R. E. Emmerick: The Khotanese Sūrañgamasamādhisūtra (1970)

*24. H. L. Shorto: A Dictionary of the Mon Inscriptions from the Sixth to the Sixteenth Centuries (1971)

*25. H. Rabie: The Financial System of Egypt, A.H. 564-741/ A.D. 1169-1341 (1972)

26. S. G. Karmay: The Treasury of Good Sayings: A Tibetan History of Bon (1972)

*27. M. A. Cook: Population Pressure in Rural Anatolia, 14501600 (1972)

28. O. Wright: The Modal System of Arab and Persian Music A.D. $1250-1300$ (1978)

*29. P. M. Thompson: The Shen Tzu Fragments (1979)

*30. M. C. Ricklefs: Jogjakarta under Sultan Mangkubumi 17491792: a History of the Division of Java (1974)

$o . p$.

o.p.

$7 \quad 00$

o.p. 
31. J. Wansbrough: Quranic Studies: Sources and Methods of Scriptural Interpretation (1977) .

*32. P. G. Robb: The Government of India and Reform, Policies Towards Politics and the Constitution 1916-1921 (1976)

*33. A. T. Hatto: The Memorial Feast for Kökötöy-khan: a Kirghiz Epic Poem (1977) .

*34. J. Wansbrough: The Secrarian Milieu: Content and Composition of Islamic Salvation History (1978)

*35. P. Ch'en: The Formation of the Early Meiji Legal Order: the Japanese Code of 1871 and its Chinese Foundation (1981)

36. A. K. S. Lambton: State and Government in Medieval Islam: an Introduction to the Study of Islamic Political Theory: the Jurists (1981)

37. S. Hopkins: Studies in the Grammar of Early Arabic (1984)

38. G. Khan: Studies in Semitic Syntax (1988) .

2500

$32 \quad 50$

3750

LONDON ORIENTAL BIBLIOGRaPHIES

1. H. R. Klieneberger: Bibliography of Oceanic Linguistics (1957)

*2. H. L. Shorto, J. M. Jacob and E. H. S. Simmonds: Bibliography of Mon-Khmer and Tai Linguistics (1963)

*3. W. R. Roff: Bibliography of Malay and Arabic Periodicals 1876-1941 (1972)

4. D. G. Chibbett, B. F. Hickman and S. Matsudaira: A Descriptive Catalogue of the pre-1868 Japanese Books, Manuscripts and Prints in the Library of the School of Oriental and African Studies (1975)

*5. M. C. Ricklefs and P. Voorhoeve: Indonesian Manuscripts in Great Britain, a Catalogue of Manuscripts in Indonesian Languages in British Public Collections (1977)

o.p.

o.p.

900

o.p.

$22 \quad 00$

Historical Writing on the Peoples of Asia

1. C. H. Philips (ed.): Historians of India, Pakistan and Ceylon (196I)

2. D. G. E. Hall (ed.): Historians of South East Asia (1961)

3. W. G. Beasley and E. G. Pulleyblank (ed.): Historians of China and Japan (1961)

4. Bernard Lewis and P. M. Holt (ed.): Historians of the Middle East (1962)

$$
\begin{array}{cc} 
& \text { o.p. } \\
& \text { o.p. } \\
& \\
& \text { o.p. } \\
& \\
& \text { o.p. } \\
& \\
& \\
& \text { o.p. } \\
& \text { o.p. } \\
2 & 00 \\
4 & 00 \\
3 & 00
\end{array}
$$

Annotated African Texts (distributed by Luzac and Co. Ltd.)

1. W. G. Atkins (ed.): Unkhoswe waaNyanja (1952) .

2. W. G. Atkins (ed.): Ukawamba (1953).

3. A. N. Tucker (ed.): Inkuti Pukunot oo IMaasai (1954)

4. B. W. Andrzejewski (ed.): Hikmad Soomaali (1956)

5. J. H. Carter (ed.): Soko Risina Musoro (1958)

\section{OTHER WORKS}

* B. W. Andrzejewski: Leopard Among the Women (Shabeelnagood): a Somali Play by Hassan Sheikh Mumin (1974)

*W. G. Beasley: Select Documents on Japanese Foreign Policy, 1853-1868 (1955)

o.p.

${ }^{*}$ L. Caplan: Administration and Politics in a Nepalese Town: The Study of a District Capital and its Environs (1975) 
M. A. Cook (ed.): Studies in the Economic History of the Middle East (1970)

J. R. Firth: Papers in Linguistics, 1934-1951 (1957) .

A. Guillaume: The Life of Muhammad (1955)

M. Guthrie: Bantu Word Division (1948)

[Published for the International African Institute]

*D. G. E. Hall: Henry Burney a Political Biography (1974)

*P. M. Holt (ed.): Political and Social Change in Modern Egypt (1968)

J. M. Jacob: Introduction to Cambodian (1968)

J. M. Jacob: A Concise Cambodian-English Dictionary (1974) .

*T. M. Johnstone: Harsūsi Lexicon (1977)

T. M. Johnstone: Jibbāli Lexicon (1982)

A. M. Jones: Studies in African Music (1959)

J. M. B. Jones: The Kitāb al-Maghāzì of al-Wāqidi (1967) .

D. J. Kamhi: Modern Hebrew: an introductory course (1982)

H. M. Lambert: Introduction to the Devanagari Script for students of Sanskrit, Hindi, Bengali, Marathi and Gujarati (1953)

H. M. Lambert: Introduction to the Devanagari Script for students of Sanskrit and Hindi (1953)

H. B. Lee: Korean Grammar (1989) .

G. H. Luce: Phases of Pre-Pagán Burma (1985) Set of two volumes

D. N. MacKenzie: A Concise Pahlavi Dictionary (1971) . .

*D. J. Matthews and C. Shackle: An Anthology of Classical Urdu Love Lyrics (1972)

* Noel Matthews and M. D. Wainwright: A Guide to Manuscripts and Documents in the British Isles relating to Africa (1971)

*Noel Matthews and M. D. Wainwright: A Guide to Manuscripts and Documents in the British Isles relating to the Far East (1977)

* Noel Matthews and M. D. Wainwright: A Guide to Western Manuscripts and Documents in the British Isles relating to the Middle East and North Africa (1980)

T. F. Mitchell: Writing Arabic (1953) Hardbound edition Paperback edition

J. W. A. Okell: A Reference Grammar of Colloquial Burmese (1969)

V. J. Parry and M. E. Yapp (ed.): War, Society and Technology in the Middle East (1975)

${ }^{*}$ C. H. Philips (ed.): The Correspondence of Lord William Cavendish Bentinck, Governor-General of India, Volume I 1828-1831, Volume II 1832-1836 (1977) . . The set

R. L. Turner: A Comparative Dictionary of the Indo-aryan Languages (1966) 
*Phonetic Analysis of the Headwords (1971)

E. Ullendorff (ed.): The Autobiography of Emperor Haile Sellassi I: 'My Life and Ethiopia's Progress' 1892-1937 (1976)

${ }^{*}$ E. Ullendorff and C. F. Beckingham: The Hebrew Letters of Prester John (1982)

*M. D. Wainwright and Noel Matthews: A Guide to Western Manuscripts and Documents in the British Isles relating to South and South East Asia (1965)

Published by George Allen and Unwin, LtD.

Studies on Modern Asia And Africa

1. C. H. Philips (ed.): Politics and Society in India (1963) .

o.p.

2. J. N. D. Anderson (ed.): Changing Law in Developing Countries (1963)

3. C. D. Cowan (ed.): The Economic Development of South East Asia (1964)

4. C. D. Cowan (ed.): The Economic Development of China and Japan (1964)

5. S. R. Mehrotra: India and the Commonwealth, 1885-1929 (1965).

6. J. N. D. Anderson (ed.): Family law in Asia and Africa (1968)

7. P. J. Vatikiotis (ed.): Egypt since the Revolution (1968).

8. D. Hopwood (ed.): The Arabian Peninsula (1972).

9. P. J. Vatikiotis (ed.): Revolution in the Middle East (1972)

10. G. N. Brown and M. Hiskett (eds.): Conflict and Harmony in Education in Tropical Africa (1975)

11. W. G. Beasley (ed.): Modern Japan: Aspects of History, Literature and Society (1975)

12. C. von Fürer-Haimendorf: The Gonds of Andhra Pradesh (1979)

o.p.

o.p.

o.p.

o.p.

o.p.

o.p.

$20 \quad 00$

o.p.

o.p.

o.p.

\section{OTHER WORKS}

R. Russell (ed.: Ghälib: the Poet and his Age (1972)

o.p.

\section{Published by The Athlone Press}

Jordan Bequest Lectures in Comparative Religion

1. L. Renou: Religions of Ancient India (1953)

2. D. Daube: The New Testament and Rabbinic Judaism (1956) .

3. P. Lévy: Buddhism: a "Mystery Religion"? (1957).

4. H. H. Rowley: Prophecy and Religion in Ancient China and Israel (1956)

5. R. C. Zaehner: Hindu and Muslim Mysticism (1960)

6. E. O. James: The Worship of the Sky-God (1963)

7. W. F. Albright: Yahweh and the Gods of Canaan (1968)

8. A. K. Cragg: The Privilege of Man (1968)

9. J. Gonda: Vișnuism and Sivaism (1970)

11. R. J. Zwi Werblowsky: Beyond Tradition and Modernity: Changing Religions in a Changing World (1976)

$$
\begin{aligned}
& \text { o.p. } \\
& \text { o.p. } \\
& \text { o.p. } \\
& \\
& \text { o.p. } \\
& \text { o.p. } \\
& \text { o.p. } \\
& \text { o.p. } \\
& \text { o.p. }
\end{aligned}
$$

12. H. W. F. Saggs: The Encounter with the Divine in Mesopotamia and Israel (1978). 
Published by LuZAC AND Co., LTD.

A. L. Basham: History and Doctrines of the Ajjivikas (195l) . o.p.

W. G. Beasley: Great Britain and the Opening of Japan (195I) . o.p.

J. Brough: Selections from Classical Sanskrit Literature (1951) second edition published by S.O.A.S.

C. C. Brown: Studies in Country Malay (1956) .

500

C. J. Dunn: The Early Japanese Puppet Drama (1966)

$5 \quad 50$

P. Hardy: Historians of Medieval India (1960) o.p.

[Reprinted by Greenwood Press, Westport, Conn., 1982]

C. Hooykaas: The Lay of Jaya Prana (1958)

J. F. P. Hopkins: Medieval Muslim Government in Barbary (1958)

B. Lewis: Handbook of Diplomatic and Political Arabic (1947) Hla Pe: Konmara Pya Zat (1952)

o.p.

o.p.

J. A. Stewart: A Manual of Colloquial Burmese, Part I (1955) .

A. S. Tritton: Materials on Muslim Education in the Middle Ages (1957)

o.p.

Published by W. HeFFer AND SONS, LTD.

*J. Berry: The Pronunciation of Ewe (1951)

J. Berry: The Pronunciation of Ga (1951)

o.p.

T. W. Clark: Introduction to Nepali (1963).

o.p.

V. Minorsky: A History of Sharvän and Darband in the 10th-11th Centuries (1958) .

J. D. Pearson: Index Islamicus (1958) [Now published by Mansell]

J. D. Pearson: Index Islamicus-First Supplement (1962) [Now published by Mansell].

Ida C. Ward: An Introduction to the Yoruba Language (1952)

Published by Lund Humphries AND Co., LTD.

${ }^{*}$ M. Boyce and I. Gershevitch (ed.): W. B. Henning Memorial Volume (1970)

F. J. Daniels (ed.): Selections from Japanese Literature (Twelfth to Nineteenth Centuries) (1959)

A. C. Graham: Two Chinese Philosophers (1958).

Yin C. Liu: Fifty Chinese Stories (1960)

o.p.

$35 \quad 00$

3500 o.p.

P. G. O'Neill: Early Nō Drama (1959)

K. P. K. Whitaker: 1200 Chinese Basic Characters for Students of Cantonese (1953)

K. P. K. Whitaker: Structure Drill in Cantonese (1954) . . o.p.

Published by CAMBridge University Press

D. Cowan: Introduction to Modern Literary Arabic (1958)

Hardbound edition

$25 \quad 00$

o.p.

o.p.

$5 \quad 95$

o.p.

o.p.

\section{Paperback edition}

*G. Innes: A Mende-English Dictionary (1969)

1195

$10 \quad 00$

A. K. S. Lambton: Persian Grammar (1953)

Hardbound edition

o.p.

Paperback edition

A. K. S. Lambton: Persian Vocabulary (1954)

Hardbound edition

o.p.

Paperback edition 
Published by The Manchester University Press

F. G. Bailey: Caste and the Economic Frontier (1957) . . . o.p.

F. G. Bailey: Tribe, Caste and Nation (1960) . . . . o.p.

Published by Routledge and Kegan Paul, Ltd.

C. C. Brown: Malay Sayings (1951) . . . . . . o.p.

Published by ENGlish Universities Press

P. G. O’Neill: A Programmed Course on Respect Language in Modern Japanese (1966)

Published by MaCMILlan and Co., LTD.

L. W. Hollingsworth: Zanzibar under the Foreign Office 1890-1913 (1953).

[Reprinted by Greenwood Press, Westport, Conn., 1976]

Published by STEvens AND Sons, LTD.

A. Gledhill: Fundamental Rights in India (1955) . . . . . o.p.

Published by Bruno Cassirer, Ltd.

D. L. Snellgrove: Four Lamas of Dolpo II (1969) . . . . $10 \quad 00$

Published by G. Bell And Sons, LTD.

R. H. Robins: Ancient and Mediaeval Grammatical Theory in Europe (1951)

Published by Arthur Probsthain

K. P. K. Whitaker: Cantonese Sentence Series (1954)

Published by Taylor's Foreign Press (Distributed by E. J. Brill)

R. B. Serjeant: Prose and Poetry from Hadramawt (1951) .

Published by Oceana Publications, Inc.

J. de V. Allen, A. J. Stockwell and L. R. Wright (ed.): A Collection of Treaties and Other Documents affecting the States of Malaysia, 1761-1963 (1981)

The set of two volumes $\$ 85.00$

Published by Franz Steiner Verlag

P. M. Holt (trans.): The Memoirs of a Syrian Prince: Abu'l-Fidā',

Sultan of Hamāh (672-732/1273-1331)

Dm. 7200

Published by University Press of America

Russell Jones: Hikayat Sultan Ibrahim ibn Adham (1985) .

Published by The Royal Asiatic Society

J. M. Jacob (trans): Reamker (Rāmakerti): the Cambodian Version of the Rāmāyaṇa (1986).

Published by The University of Natal Press

D. K. Rycroft and A. B. Ngcobo (ed.): The Praises of Dingana

(izibongo zikaDingana) (1988) 


\section{New from E.J. Brill of Leiden/New York}

\section{Hebrew in its West Semitic setting}

A comparative survey of non-Masoretic

Hebrew dialects and traditions

Part 2. Phonetics and phonology.

Part 3. Morphosyntactics

A. MURTONEN

This work is a survey of non-Masoretic Hebrew dialects and traditions against the background of the related, primarily other West Semitic languages, but also the less close East and South Semitic and non-Semitic branches of the Semito-Hamitic phylum are taken into account.

1990. (xiii, 548 p., 12 tables, 16 pl.)

$\left[\begin{array}{lllll}90 & 04 & 09309 & 5\end{array}\right]$

cloth Gld. 265.-/US\$151.50

\section{A history of Zoroastrianism MARY BOYCE}

'...the first important original interpretation of early Iranian religion to have appeared in English...'

J.C. WRIGHT, Bulletin S.O.A.S.

'...this book is a remarkable achievement and represents a milestone in Zoroastrian studies...'

G. Morrison, Society for O.T.S. Booklist Vol. 1: The early period. Rev. ed. 1989. (xvi, 349 p.) [90 0408874 4]

Gld. 165.-/US\$ 94.50

Vol. 2: Under the Achaemenians. 1982.

(xvi, 306 p.) [900406506 7]

Gld. 144.--/US\$82.50

Vol. 3: Under Macedonian and Roman rule. With FRANTZ GRENET. February 1991. (ca. 660 p.) [900409271 4]

cloth Gid. 380.-/US\$ 217.25

Vol. 4: Under the Parthians and the early

Sasanians.

in preparation

\section{al-Hind}

The making of the Indo-Islamic world ANDRÉ WINK

This work aims to analyze the process of momentous and long-term change which came with the Islamization of the regions which the Arabs called AL-HIND, that is India and large parts of its Indianized hinterland.

1. Early medieval India and the expansion of Islam 7th-11th centuries.
1990. (viii, 396 pages, 15 maps) [90 04092498 ]

cloth Gld. 165.-/US\$ 94.50

In preparation.

2. The slave kings and the Islamic

conquest of India 11 th-13th centuries.

3. Indo-Muslim society 14 th -15 th

centuries.

4. Imperial formations 16th-17th

centuries.

5. State and society in the eighteenth century.

\section{The State in Indian Tradition}

\section{HARTMUT SCHARFE}

The State in Indian Tradition deals with the concept and actualization of the state in India and the developments leading up to the formation of the state, essentially from the Vedic period until the Muslim conquest. At the same time, the author has attempted to distinguish the characteristic phases in this historic process.

1989. (ix, 265 p.) [90 04090606 6]

Gld. $129 .-/$ US $\$ 64.50$

\section{The History and the Life of}

\section{Chinggis Khan}

(The Secret History of the Mongols)

\section{URGUNGE ONON}

This is the first translation written by a native Mongol scholar in English of the 13th century History and Life of Chinggis Khan, founder of the Mongol Empire.

1990. xix, 182 pages, map

[90 0409236 6]

$$
\text { cloth Gld. } 90 .-/ \mathrm{US} \$ 51.50
$$

\section{Asia's First Modern Revolution}

Mongolia proclaims its independence in 1911

URGUNGE ONON and

DERRICK PRITCHATT

This is an account of the developments leading up to the proclamation of independence by Mongolia in 1911. It includes documents never before translated or published outside Mongolia.

1989. (xi, 203 p., richly ill., map)

[900408390 1]

cloth Gld. 118.,/US\$67.50

\section{E.J. Brill publishers since 1683}

P.O.B. 9000 - 2300 PA Leiden - The Netherlands

24 Hudson Street • Kinderhook, NY 12106 • U.S.A.

Call toll-free 1-800-962-4406 (U.S. only)

Prices are utbjeat to change withou priar notice and are excluaive of handing coots. USS prices are valid for U.S. and Candian curtomere only. 


\section{NATIONAL UNIVERSITY OF SINGAPORE DEPARTMENT OF CHINESE STUDIES}

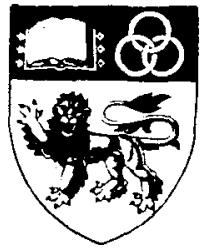

Applications are invited for teaching appointments in the Department of Chinese Studies from candidates who possess a relevant PhD degree. Preference will be given to those who are able to teach in at least two of the following areas:

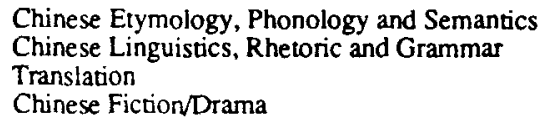

The medium of instruction is Chinese; however, candidates must also be able to teach in English.

Besides appointments on normal 3-year contacts, visiting appointments for one or two years will also be considered.

Gross annual emoluments range as follows:

$\begin{array}{lc}\text { Lecturer } & \$ \$ \$ 0,390-64,200 \\ \text { Senior Lecturer } & \$ \$ 58,680-100,310 \\ \text { Associate Professor } & \$ \$ 88,650-122,870 \\ \text { (STG } 1.00=\$ \$ 3.34 \text { approximately) }\end{array}$

The commencing salary will depend on the candidate's qualifications, experience and the level of appointment offered.

Leave and medical benefits will be provided. Depending on the type of contract offered, other benefits may include: provident fund benefits or an end-of-contract gratuity, a settling-in allowance of $\$ \$ 1,000$ or $S \$ 2,000$, subsidised housing at nominal rentals ranging from $S \$ 100$ to $\$ \$ 216$ p.m., education allowance for up to three children subject to a maximum of $\$ \$ 10,000$ per annum per child, passage assistance and baggage allowance for the transportation of personal effects to Singapore. Staff members may undertake consultation work, subject to the approval of the University, and retain consultation fees up to a maximum of $60 \%$ of their gross annual emoluments in a calendar year.

The Department of Chinese Studies is a department in the Faculty of Arts and Social Sciences. There are 8 faculties in the National University of Singapore with a current student enrolment of some 14,000. All departments are well-equipped with a wide range of facilities for teaching and research.

All academic staff have access to the following computer and telecommunication resources: an individual mictocomputer (an IBM AT-compatible or Apple Macintosh); an IBM mainframe computer with 16 MIPS of computing power; an NEC SX supercomputer with 650 MFLOPS of computing power; departmental laser printers; a wide spectrum of mainframe and microcomputer software; voicemail; BITNET to access academic institutions world-wide. An on-line library catalogue is also available. In addition, a new campus network based on state-of-the-an optical fibre technology has been installed to facilitate resource sharing and electronic communication for the academic community. from:

Application forms and further information on terms and conditions of service may be obtained

The Director

Personnel Department

National University of Singapore

10 Kent Ridge Crescent

Singapore 0511

\author{
NUS Overseas Office \\ Singapore High Commission \\ (Students Department) \\ 16 Kinnerton Street, \\ London SW $1 X$ 8ES, U.K. \\ Tel: (071) 235-4562
}

Enquiries may also be sent through BITNET to: PERJC @ NUS3090. or through Telefax: (65)7783948. 


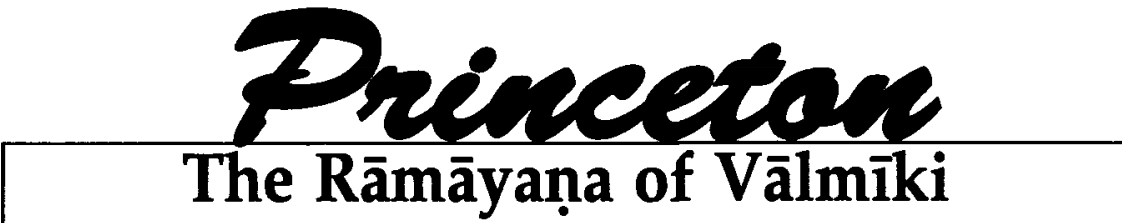 An Epic of Ancient India Volume III, Araṇyakāṇ̣̣a Introduction, translation, and annotation by Sheldon I. Pollock \\ Edited by Robert P. Goldman \\ This is the third volume of a planned seven-volume translation of India's most beloved and influential epic tale-the Rāmāyana of Vālmiki. The book contains the narrative center of the epic, the abduction of Sīta by the demon king Rāvana. It provides a profound meditation on the paradox of the hero as both human and divine. The present translation seeks to provide a readable and trustworthy English version of the poem. It is accompanied by a full commentary elucidating the philol- ogical, aesthetic, and cultural problems of the text. \\ Princeton Library of Asian Transiations \\ Cloth: $\$ 65.00$ ISBN 0-691-06660-4
}

\section{Encyclopedia of Indian Philosophies}

\section{Karl H. Potter, Editor}

\section{Volume V: The Philosophy of the Grammarians}

\author{
Harold G. Coward and K. Kunjunni Raja, Editors
}

This volume of the monumental reference series provides summaries of the main works in the Grammarian tradition of Indian philosophy. Special emphasis is placed in this volume on the thought of Bhartrhari, the great systematizer of the Grammarian philosophy.

Cloth: $\$ 55.00$ ISBN 0-691-07331-7

Not abailable from Princeton in India

\section{New in paperback}

With a new preface by Joseph M. Kitagawa

\section{Norito}

\section{A Translation of the Ancient Japanese Ritual Prayers \\ Donald L. Philippi}

This volume presents the only English translation of the prayers of Japan's indigenous religious tradition, Shintō. These prayers, norito, are works of religious literature that are basic to an understanding of Japanese religious history.

Composed in the stately ritual language of the ancient Japanese and presented as a "performing text," these prayers are now available in a definitive paperback edition.

Now in paper. \$9.95 ISBN 0-691-01489-2

\section{PRINCETON UNIVERSTTY PRESS \\ 41 WILLIAM ST. - PRINCETON, NJ 08450 • (609) 258-4900 ORDERS: 800-PRS-ISBN (777-4726) (OR FROM YOUR LOCAL BOOKSTORE)}

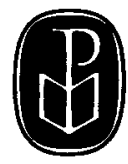

BULL. of the SCHOOL of ORIENT. \& AFRIC. STUDIES 2/91 NEWNOV ADS $1 \quad 91-314$ 


\section{OXFORD UNIVERSITY PRESS}

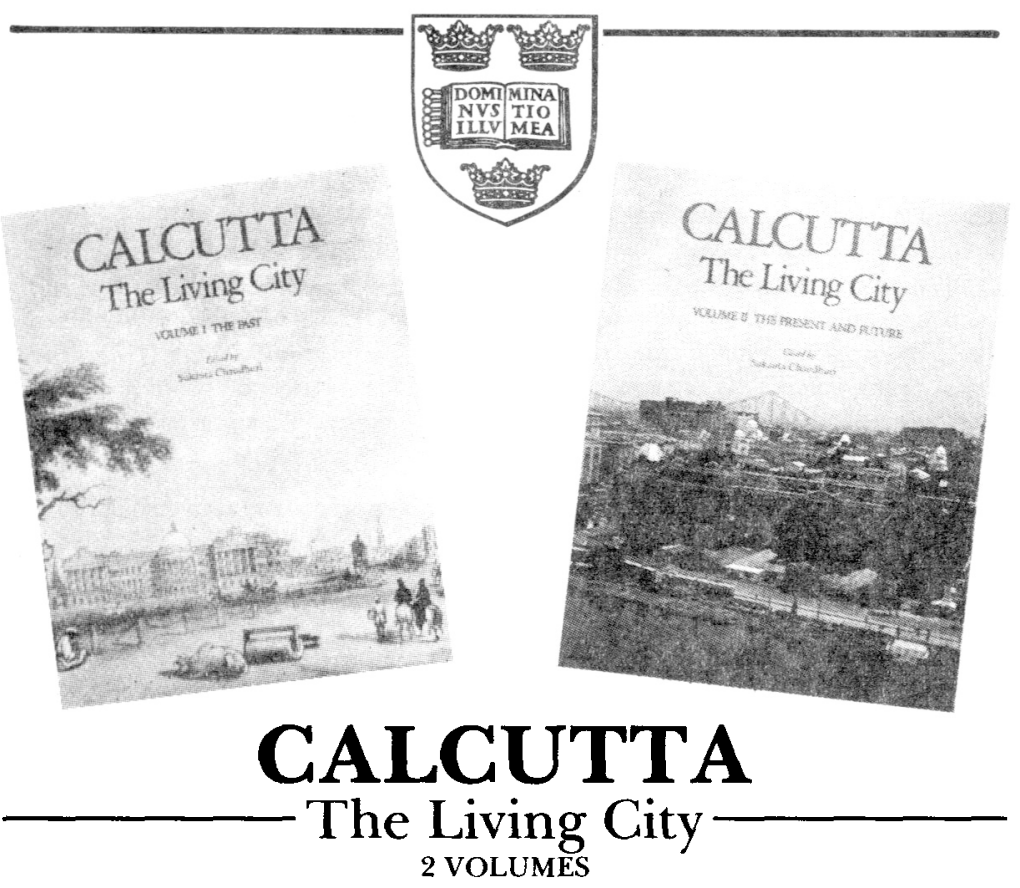

Edited by Sukanta Chaudhuri

Written by Calcutta's most noted scholars, writers, and artists, these lavishly illustrated books celebrate the tercentenary of India's most vibrant city. Vol I: 232pp., 0-19-562585-4, £25 Vol II: 3 I2pp., 0-19-562586-2, £30

\section{SAHIBS, NABOBS, AND BOXWALLAHS}

\section{The Words of Anglo-India-}

Ivor Lewis

Containing over 4,000 headwords, this rich mine of information captures the full colour and spice of the Anglo-Indian vocabulary.

350 pp., 0-19-562582-X, £25

February

\section{LIFE AMONG INDIAN TRIBES}

\section{The Autobiography of an Anthropologist}

Christoph von Fürer-Haimendorf

A fascinating memoir of life among the hunters, nomads, farmers, and headhunters of India and Nepal.

170 pp., 20 b/w illus., 0-19-562471-8, £10.95

\section{THE ORIGINS OF THE PARTITION OF INDIA}

\section{6-1947}

\section{Anita Inder Singh}

An important reassessment of the British U-turn that led to the dissolution of the Raj and the formation of a sovereign Pakistan.

286 pp., 0-19-562541-2, £3.99 


\title{
Just Published ... .
}

\author{
A GLOSSARY OF SUFI TECHNICAL TERMS \\ 'Abd al-Razzaq al-Qashani \\ Translated by $\mathrm{Dr}$. N. Safwat \\ Revised and edited by $D$. Pendlebury
}

Required reading in Sufi circles for six-and-a-half centuries, this is the first readily accessible translation from the Arabic into a Western language. With a new index to the English text, copious notes and a facsimile version of the original Arabic text, this work is intended for the serious student.
Hardback
ISBN 0863040322
$£ 20.00$

\section{THE DERVISHES OF TURKEY}

by Lucy M. J. Garnett with a foreword by Omar M. Burke

This book provided source material for many orientalists, as Omar Burke's foreword makes clear. It presents information collected in Ottoman Turkey in the early part of this century about the Dervish orders as Ms. Garnett perceived them.

Hardback

ISBN 0863040527

\section{SUFI THOUGHT AND ACTION}

An Anthology of Important Papers with a New Introductory Essay by Idries Shah Previously published only as separate monographs, this collection of papers covers the extraordinary diversity of Sufi ideas and activities in many cultures and countries. Nothing approaching such a survey has ever been put together before.

Soft Cover

ISBN 0863040519

\section{A DERVISH TEXTBOOK}

From the Awarifu-I-Ma'arif of Sheikh Shahabuddin Suhrawardi

Translated by $\boldsymbol{H}$. Wilberforce-Clarke

'Used as a manual for the study of Sufism by the Sufis of all orders'

Hardback

$$
\text { ISBN } 0900860731
$$

Rev. John Subhan, Sufism

\section{THE ASSEMBLIES OF AL-HARIRI \\ Retold by Amina Shah}

From the Makamat of Al-Hariri of Basra, these adventures of the rascally Abu Zayd have, for eight centuries been regarded as the greatest treasure in Arabic literature after the Qur'an. The tales and events mirror the antics of the human mind on its way through life.

Hardback

ISBN 0900860863

THE OCTAGON PRESS LTD.

P.O. Box 227, London N6 4EW

Telephone: 081-348 9392

Fax: 081-341 5971

Credit cards accepted 


\section{MOTILAL BANARSIDASS}

\section{INDOLOGICAL PUBLISHERS \& DistRIBUTORS}

\section{New \& Forthcoming Titles}

The Bhardvajas in Ancient India-Thaneswar Sarmah $x$ lv, $383 p$. ISBN: $-0639-5$

The Bhadra-Mayakara-Vyakarana-Konstanty Regamey

xviii,138p. Abbrev., Index, Notes, Ref.

ISBN: $-0761-8$

The Buddha Nature: A Study of the Tathagatagarbha and Alayavijnana-Brian E. Brown xliv,448p. ISBN: -0631-x

A Comparative Study of Religions- $Y$. Masih $x$ iv,399p. ISBN: $-0743-x$

Foundations of Indian Culture:Vol.I: Spiritual Vision and Symbolic forms in Ancient India; Vol.Il: Dimesions of Ancient Indian Social History-G.C. Pande

Vol. I: xiv,378p. Biblio., Illus., Index; Vol. I: vii, 284p. Biblio., Index. ISBN: $-0712-x$ (set)

Gadadhara's Theory of Objedivity: Containing the Text of GADADHARA'S Visayatarada with an English Introduction, Explanatory Notes and a General Introduction (2 Parts)-Sibajiban Bhattacharya

Pt. 1: x, 195p. Biblio., Figs., Index. ISBN: $-0461-9$ Pt. 2: xii,188p. Figs. ISBN: $-0822-3$

INDIA: Mystic, Complex and Real (An Interpretation of E.M. Forster's A Passage to India)Adwaita Pada Ganguly xvii,329p.+Plates, Illus., Maps, Abbrev., Append., Biblio., Index, Notes. ISBN: -0628-x

J. Krishnamurti and Sant Kabir-Rohit Mehta \& Shridevi Mehta

vii,183p. ISBN: $-0667-0$

Ludwig Alsdorf And Indian Studies-Klaus Bruhn \& Others Eds.

xii,102p.+Plate, Biblio. ISBN: $-0681-6$

The Lion's Roar Of Queen Srimala: A Buddhist Scripture on the Tathagatagarbha Theory--Alex Wayman \& Hideko Waymen Tr.

xvii,142p. Append., Biblio., Gloss, Index. ISBN: $-0731-6$

The Noun Phrase in Bengali: Assignment of Role and the Karaka Theory-Malaya Gangopadhyaya $x i v, 358 p$. Table, Append., Biblio., Index. ISBN: $-0377-9$

Padma Purana: Ancient Indian Tradition And Mythology Vol. 39-48 (Translation of Mahapu- ranas planned in hundred volumes out of which translations of Linga, Bhagavata, Garuda, Narada, Kurma, Brahmanda, Agni, Varaha, Brahma, Vayu and Padma Purana have already appeared. Translations of other Puranas are under preparation)

Phenomenology and Indian Philosophy-D.P. Chat topadhyaya, Lester Embree \& fitendranath Mohanty Eds.

viii, $327 \mathrm{p}$. ISBN: $-0770-7$

Philosophy In The Samadhirajasutra-Konstanty Regamey vi,113p. Abbrev. Index, Notes, Ref. ISBN: $-0763-4$

Principles of Composition in Hindu Sculpture: Cave Temple period-Alice Boner $x v i i, 274 p .+25$ Plates. Append., Index ISBN: $-0705-7$

Samvada: A Dailogue Between Two Philosophical Traditions-Daya Krishna et al Eds. xlviii, 227p. Append., Index. ISBN: -0798-7

The Scientific Foundation Of Jainism-K.V. Mardia xix,121p. Illus., Charts, Diagrs., Fig., Append., Biblio., Index. ISBN: -0694-8

Self And Its States: A States of Conscious Doctrine in Advaita Vedanta-Andrew O'Fort xix,226p. Abbrev., Biblio., Index, Notes. ISBN: $-0633-6$

The Seven Great Untenables: Sapta-Vidha Anupapatti-John Grimes xiv,130p. Biblio., Index. ISBN: $-0682-4$

Sudha (Nectar)-Chalam (Translated by J.S.R.L. Narayana Moorty) $x x, 116 p$. ISBN:-0614-x

Suresvara's Vartika On Asva and Asvamedha Brahmana-Shoun Hino \& Jog K.P. Tr. xviii,110p. Gloss., Index ISBN: $-0643-3$

Vedic Text: A Revision (Prof. C.G. Kashikar Felication Volume)-T.N. Dharmadhikari Ed. xii,134p. Ref. ISBN: -0806-1

U.K. DISTRIBUTORS MOTILAL BOOKS (U.K.) LTD. 52, CROWN ROAD WHEATLEY OXFORD OX9IUL

ISBN PREFIX: 81-208

Motilal Banarsidass Publishers Pvt. Ltd. 41 U.A., Bangalow Road, Jawahar Nagar, Delhi-110007 ISSUED BY CHEMICALS \& ALLIED PRODUCTS EXPORT PROMOTION COUNCIL, CALCUTTA, INDIA. 


\section{Cambridge}

\section{The Isma'ilis: Their History and Doctrines FARHAD DAFTARY}

Based on more than twenty years of personal study by Dr Daftary, this new book traces the history and doctrinal development of the Isma'ili movement from its origins to the present day. It covers all twelve centuries of Isma'ili history and is the most definitive account available in any language.

£60.00 net HB $0521370191822 \mathrm{pp}$.

\section{The Cambridge History of Japan}

Volume 3: Medieval Japan

Edited by KOZO YAMAMURA

Spanning three and a half centuries in 13 specially commissioned essays, this volume describes a period when the warrior class ruled Japan, institutions underwent fundamental transformations, the economy grew and Japanese culture evolved with such vitality that its legacy is still apparent today.

$£ 70.00$ net HB $0521223547 \quad 734$ pp.

\section{The Golden Age of the Chinese Bourgeoisie} 1911-1937

\section{MARIE-CLAIRE BERGERE}

This innovative study looks at the gradual establishment of the bourgeoisie as a specific and coherent social class in China. Bergere describes how, even though the bourgeoisie had their own political ideology, they were unable to establish any formal authority in the aftermath of the state's collapse.

$£ 37.50$ net HB $0521320542288 \mathrm{pp}$.

Studies in Modern Capitalism

Co-publication with the Maison des Sciences de I'Homme

\section{'Abbasid Belles-Lettres}

Edited by JULIA ASHTIANY, T. M. JOHNSTONE, J. D. LATHAM,

\section{R. B. SERJEANT and G. REX SMITH}

This volume of The Cambridge History of Arabic Literature covers artistic prose and poetry produced in the heartland and provinces of the 'Abbasid empire during the second great period of Arabic literature, from the mid-eighth to the thirteenth centuries $A$. D. E60.00 net HB $0521240166 \quad 517$ pp.

The Cambridge History of Arabic Literature

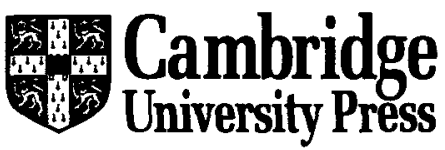

The Edinburgh Building, Cambridge CB2 2RU, UK. 
父司

Stephen

子 提 Austin

有 芬 and

限 奥 Sons

公 司 Limited for printing in all the

司丁

for printing
in all the
world's
languages

Caxton Hill Ware Road Hertford

Hertford 584955 